\title{
FAKTOR HEREDITAS DAN LINGKUNGAN DALAM MEMBENTUK KARAKTER
}

\author{
Dea Nerizka, Eva Latifah, dan A. Munawwir \\ Universitas Islam Negeri Sunan Kalijaga Yogyakarta Indonesia \\ E-mail: Nerizkadhean@gmail.com
}

\begin{abstract}
Abstrak: Setiap manusia diciptakan dengan berbagai macam keunikannya dengan karakteristik masing-masing. Faktor hereditas dan lingkungan dipandang sebagai faktor yang mempengaruhi proses pembentukan karakteristik setiap individu. Hereditas dipandang sebagai faktor bawaaan yang di turunkan dari orang tua pada anak baik fisik maupun psikis sejak masa konsepsi melalui gen-gen. Penelitian ini bertujuan untuk mengkaji lebih dalam faktor hereditas dan lingkungan dalam membentuk karakter dengan titik fokus melihat pada faktor manakah yang lebih dominan dalam pembentukan karakter individu. Penelitian ini merupakan penelitian kepustakaan. Sumber data dalam penelitian ini berupa buku-buku, jurnal dan situs-situs dari internet yang memiliki kaitan dengan topik yang diteliti. Teknik pengumupan data dalam penelitian ini yaitu studi dokumen. Analisis data menggunakan analisis isi (content analysis). Berdasarkan hasil studi yang dilakukan, penulis menemukan bahwa faktor hereditas dalam diri individu dipandang mempengaruhi dalam perkembangan jasmani seperti warna kulit, warna mata, jenis rambut, dan sebagainya. Beberapa bentuk kepribadian dan perilaku sosial dapat merujuk pada faktor lingkungan.
\end{abstract}

Kata Kunci: hereditas, lingkungan, karakter

\section{HEREDITY AND ENVIRONMENT FACTORS IN BUILDING CHARACTERS}

Abstract: Every human being is created with a variety of uniqueness with each characteristic. Heredity and environmental factors are seen as factors that influence the process of forming the characteristics of each individual. Heredity is seen as a hereditary factor that is passed down from parents to children both physically and psychologically since the conception through genes. This study aims to examine more deeply the heredity and environmental factors in shaping character with a focus point to see which factors are more dominant in shaping individual characters. This research is a type of library research. The data sources in this study are books, journals and websites from the internet that are related to the topic under the study. The data collection technique in this research is document study. The data analysis used content analysis. Based on the results of the study conducted, the authors found that heredity factors in individuals are seen as influencing physical development such as skin color, eye color, hair type, and so on. While some forms of personality and social behavior can refer to environmental factors.

Keywords: heredity, environment, character

\section{PENDAHULUAN}

Manusia merupakan makhluk yang diciptaan Allah Swt. dalam bentuk paling sempurna dibanding dengan makhluk ciptaan lainnya. Struktur manusia terdiri atas dua unsur pokok, yakni jasmani (fisiologis) dan rohani (psikologis). Dalam kedua unsur itu Allah Swt. memberikan kemampuan dasar atau potensial yang mampu berkembang (Daimah \& Niam, 2019).

Pada hakikatnya manusia diciptakan dengan berbagai macam keunikannya de- ngan karakteristik masing-masing. Keunikan karakteristik setiap individu tentu tidak muncul dengan sendirinya. Terdapat sebuah proses yang harus dilewatinya sehingga karakteristik tersebut dapat menjadi sebuah karakter yang melekat dalam diri setiap individu.

Faktor hereditas dan lingkungan dipandang sebagai faktor yang berpengaruh dalam proses pembentukan karakteristik setiap individu. Maragustam (2018) menjelaskan karakter tidak dapat diwariskan 
yang oleh karenanya sebuah karakter harus diciptakan, diukir, dan dibangun setiap harinya melalui sebuah proses yang panjang. Ia menyatakan sebuah karakter tidak sama dengan sidik jari yang tidak dapat diubah dan merupakan faktor bawaan. Setiap individu berpotensi untuk dapat menjadi pribadi yang berkarakter atau tuna karakter. Maragustam juga menegaskan apabila karakter merupakan seratus persen berasal dari faktor bawaan (hereditas), maka karakter tidak akan dapat dibentuk lagi, namun apabila faktor bawaan hanyalah merupakan salah satu dari faktor yang dapat membentuk karakter, maka karakter tersebut akan dapat dibentuk yakni sejak usia dini. Di samping faktor dalam diri (hereditas), pembentukan karakter juga dipengaruhi oleh faktor lain berupa alam, sosio-kultural, keluarga tradisi, pendidikan, media sosial, dan lain-lain (Tibahary \& Muliana, 2018).

Hereditas juga berpengaruh besar terhadap perkembangan anak. Hasil penelitian yang dilakukan oleh Amini \& Naimah (2020) menegaskan bahwa gen yang diterima anak dari orang tuanya pada saat pembuahan akan mempengaruhi semua karakteristik dan penampilan anak dalam perjalanan hidupnya kelak. Yang diturunkan orang tua kepada anaknya yaitu sifat strukturnya, bukan tingkah laku yang diperoleh sebagai hasil belajar atau pengalaman seperti bakat, sifat-sifat keturunan, intelligensi dan juga kepribadiannya. Dengan demikian, faktor hereditas ini memberikan pengaruh lebih besar terhadap perkembangan intelligensi seorang anak dibanding dua faktor lainnya yaitu faktor lingkungan dan faktor umum.

Dalam salah satu penelitian yang mengkaji hereditas, Sholihah \& Niam (2019) dinyatakan bahwa faktor hereditas dan lingkungan merupakan faktor yang dapat mempengaruhi perbedaan individu. Faktor hereditas dan lingkungan bersama-sama mempengaruhi proses pembentukan kepribadian manusia dengan ijin Allah Swt. Sedangkan proses pembelajaran dapat dinilai sebagai proses kunci dalam pembentukan kepribadian manusia dengan mempertimbangkan berbagai perspektif dalam menjalankan aktivitas pembelajaran. Dua faktor tersebut (hereditas \& lingkungan) berengaruh dalam proses pertumbuhan dan perkembangan seorang peserta didik. Kemungkinan dari dua faktor tersebut terdapat faktor yang lebih dominan, akan tetapi baik faktor hereditas maupun faktor lingkungan sama-sama memiliki pengaruh antarindividu yang satu dengan yang lainnya tidak akan sama meskipun dilahirkan secara kembar.

Berdasarkan data yang dipaparkan di atas dapat dipahami bahwa karakter yang ada dalam diri manusia bukan hanya merupakan bawaan sejak lahir melainkan harus diciptakan melalui sebuah proses panjang sejak manusia itu dilahirkan hingga dewasa agar karakter tersebut melekat dalam pikiran serta membentuk keyakinan dan prinsip yang kuat. Penelitian ini dilakukan untuk mengkaji faktor hereditas dan lingkungan dalam pembentukan karakter dengan titik fokus menganalisis faktor-faktor manakah yang lebih dominan dalam pembentukan karakter seorang individu. Masalah pokok yang dikaji yaitu bagaimana faktor hereditas mempengaruhi pembentukan kepribadian/karakter manusia, dan bagaimana faktor lingkungan mempengaruhi pembentukan kepribadian/karakter manusia.

\section{METODE}

Penelitian ini merupakan penelitian kepustakaan (library research). Penelitian kepustakaan (studi pustaka) digunakan 
untuk mengumpulkan data dan informasi dengan berbagai macam bahan atau material yang terdapat di perpustakaan baik berupa buku, kisah sejarah, dokumen, majalah, dan lain sebagainya (Mirzaqon, 2018). Studi kepustakaan juga digunakan untuk mempelajari beragam buku referensi dan hasil-hasil penelitian sebelumnya yang serupa dengan permasalahan yang hendak diteliti (Sarwono, 2006).

Sumber data dalam penelitian ini berupa buku-buku, jurnal dan situs-situs dari internet yang memiliki kaitan dengan topik yang sedang penulis teliti. Sumber data dalam penelitian ini terdiri dari dua buku dan jurnal-jurnal yang terkait tentang faktor hereditas dan lingkungan dalam pembentukan karakter. Teknik pengumpulan data yang digunakan yakni studi dokumen dengan mencari data mengenai variabel-variabel atau hal-hal berupa buku, catatan, artikel dan makalah, jurnal, dan lain sebagainya.

Penelitian ini menggunakan analisis isi (content analysis). Analisis ini diguankan untuk mendapat sumber atau referensi yang valid dan dapat diteliti kembali berdasarkan konteksnya. Proses pemilihan, pembandingan, penggabungan serta pemilahan berbagai pengertian digunakan dalam analisis ini hingga menemukan yang relevan (Mirzaqon, 2018).

\section{HASIL DAN PEMBAHASAN}

\section{Hereditas dalam Pembentukan Karakter Manusia}

Istilah heritabilitas digunakan oleh para psikolog dan ilmuan untuk menentukan seberapa banyak faktor keturunan berpengaruh dalam suatu karakteristik tertentu. Berdasarkan hal itu digunakanlah istilah rasio heritabilitas untuk melihat proporsi variabilitas karakteristik tertentu yang berasal dari faktor keturunan. Heritabilitas dapat bervariasi mulai dari 0.0 yang berarti tidak memiliki perbedaan yang berakar dari faktor keturunan hingga 1.0 yang berarti semua perbedaan berakar dari faktor keturunan dalam diri manusia (Stenberg \& Preiss, 2010).

Berdasarkan pandangan hereditas, gen yang berasal dari karakteristik bawaan yang diwariskan (genotip) oleh orang tua dapat mempengaruhi karakteristik seorang individu. Gen tersebut kemudian akan terlihat sebagai karakteristik tertentu yang dapat diobservasi (fenotip) (Amini \& Naimah, 2020). Hereditas juga merupakan faktor utama yang berpengaruh dalam perkembangan individu. Dalam hal ini hereditas diartikan sebagai totalitas karakteristik individu yang diturunkan orang tua pada anak atau segala bentuk potensi, baik fisik maupun psikis yang dimiliki individu sejak masa konsepsi masa pertumbuhan ovum oleh sperma sebagai warisan dari orang tua melalui gen-gen. Dengan demikian, hereditas ialah pewarisan (pemindahan) biologis, berupa karakteristik individu dari pihak orang tua kepada anaknya (Fathurrohman, 2016).

Hereditas merupakan kecenderungan dalam bentuk alami yang berasal cabang-cabang untuk meniru sumber semula dalam aspek fisik dan psikologis. Ahli hereditas menggambarkan hereditas sebagai salinan cabang-cabang dari sumbernya (Daimah \& Niam, 2019). Secara sederhana, hereditas dapat diartikan sebagai pemindahan sifat dari generasi ke generasi melalui proses reproduksi (Pratiwi, Mufliha, \& Adini, 2020).

Setiap individu mengawali kehidupannya sebagai organisme bersel tunggal, berukuran sangat kecil. Sel tersebut merupakan gabungan dari sel telur atau ovum an sel sperma atau spermatozoid. Penggabungan kedua sel tersebut menghasilkan 
nukleus (inti) yakni seorang individu baru. Dalam tiap sel terdapat inti sel atau nukleus. Inti sel tersebut berbeda dengan sel lainnya (sel badan). Hal tersebut dapat dilihat dari perbedaan fungsi kedua sel tersebut. Sel badan dalam diri individu berfungsi sebagai penahan keseimbangan, penggerak otot, penghubung syaraf, dan lain sebagainya. Adapun sel benih memiliki fungsi yang khusus yakni untuk membentuk individu baru. Sel benih inilah yang hanya dapat menentukan penurunan sifat dalam diri individu (Amini \& Naimah, 2020).

Pada tiap organisme, baik tumbuhan, binatang maupun manusia, setiap sel tubuhnya memiliki sejumlah kromosom. Adapun manusia memiliki 48 kromosom. Kromosom manusia berasal dari Bersatunya ovum (ibu) dan sperma (ayah) yang masing-masing memiliki latar belakang keturunan berbeda-beda. Hal tersebut yang menjadikan macam-macam bentuk wajah dan tubuh pada laki-laki dan perempuan (Pratiwi, Mufliha, \& Adini, 2020). Tiap-tiap kromosom mengandung sejumlah gen (Amini \& Naimah, 2020). Diperkirakan setiap individu memiliki kurang lebih 12.000 pasang gen. Gen-gen tersebutlah yang akan menentukan sifat-sifat keturunan seperti warna rambut, warna mata, warna kulit, tinggi badan, bentuk hidung, dan lain sebagainya (Pratiwi, Mufliha, \& Adini, 2020).

Beberapa prinsip hereditas menurut Crow and Crow (Fathurrohman, 2016, Daimah \& Niam, 2019) yaitu sebagai berikut.

1. Prinsip reproduksi. Dalam prinsip reproduksi, faktor keturunan (hereditas) berlangsung melalui perantara germ cell dan tidak dengan cell somatic. Sifat-sifat orang tua yang didapat dari lingkungan tidak dapat mempengaruhi germ cell (plasma benih). Misalnya, seorang Ibu yang kompeten dalam ilmu kedokteran maka anaknya tidak dengan otomatis menjadi dokter ahli akan tetapi harus belajar tentang kedokteran terlebih dahulu. Pendidikan berpotensi untuk dapat membangun motivasi dan memberikan fasilitas yang dapat mendorong anak untuk belajar sesuai dengan cita-cita anak, akan tetapi juga perlu didasarkan kesiapan anak dan tak memaksakan anak untuk belajar sesuai dengan keinginan orang tuanya.

2. Prinsip konformitas. Berdasarkan prinsip konformitas, masing-masing makhluk menurunkan golongan dan jenisnya sendiri. Ciri-ciri biologis, warna kulit, bentuk tubuh atau jasmani dan sebagainya adalah hal-hal yang dapat diturunkan. Maknanya, bahwa lingkungan tidak dapat mengubah individu menjadi individu lain. Meskipun kemajuan teknologi mungkin dapat mengubah, hal ini bertentangan dengan prinsip etika kemanusiaan.

3. Prinsip variasi. Dalam prinsip variasi, suatu jenis atau spesies dipandang dapat memiliki persamaan maupun perbedaan.

4. Prinsip regresi filial. Ciri khas yang ada pada seorang anak akan menunjukkan ke arah rata-rata. Hal ini dapat diartikan bahwa orang tua merupakan pembawa bukan produsen, kemungkinan orang tua memiliki kombinasi sel baik dan dominan, sedangkan anak memungkinkan untuk memiliki sel yang kurang baik sehingga kualitas anak juga kurang ataupun sebaliknya. Oleh karena itu, terdapat kemungkinan jika anak dari orang tua yang memiliki kecerdasan baik terdapat kecenderungan kecerdasan yang kurang. Sebaliknya, anak dari ayah/ibu yang kurang cerdas dapat memiliki kecerdaan yang lebih cerdas dibandingkan orang tuanya. Prinsip ini 
memicu minat bagi pendidik ataupun psikolog untuk meneliti secara lebih cermat, yaitu apa saja faktor-faktor dari luar yang dapat mempengaruhi keadaan tersebut.

5. Prinsip jenis silang. Dalam prinsip menyilang, sesuatu yang diwariskan kepada anak dari orang tua mempunyai sasaran dalam jenis menyilang. Anak perempuan akan cenderung memiliki banyak sifat-sifat dan tingkah laku dari ayahnya, sedangkan anak laki-laki akan cenderung banyak menurun sifat-sifat dan tingkah laku dari ibunya.

Dalam disiplin ilmu pendidikan, seseorang yang percaya bahwa faktor hereditas mempengaruhi perkembangan seorang individu disebut aliran nativisme. Pelopor aliran ini yaitu Schopenhaue. Aliran ini berpendapat bahwa sejak lahir perkembangan seorang anak ditentukan oleh faktor bawaan. Aliran ini menolak pengaruh lingkungan dan pendidikan dalam perkembangan seseorang. Asumsi yang mendasari aliran ini ialah bahwa kepribadian antara seorang anak dan orang tua memiliki banyak kesamaan baik dalam segi fisik dan psikis. Setiap manusia dalam dirinya memiliki gen dan gen tersebutlah yang dipindahkan oleh orang tua kepada anak (Amini \& Naimah, 2020).

Berdasarkan pandangan kaum yang menekankan masalah hereditas seperti itu, perkembangan seorang individu akan dipengaruhi oleh hal-hal berikut ini.

1. Bakat. Seorang anak dilahirkan dengan membawa berbagai macam bakat sebagai pembawaannya, bakat-bakat tersebut dapat berupa bakat dalam bermusik, seni, agama, dan lain sebagainya. Bakat yang dimiliki seorang anak inilah yang diturunkan dari orang tua, baik dari ibu, bapak, maupun nenek moyangnya.
2. Sifat-sifak keturunan. Sifat keturunan yang dipindahkan dari orang tua atau nenek moyang terhadap diri anak dalam bentuk fisik dan psikis. Dalam bentuk fisik seperti bentuk tubuh, hidung, atau dapat berupa suatu penyakit turunan. Adapun dalam bentuk psikis dapat berupa sifat pemarah, pemalas, cemas, pandi berbicara, kepandaian, dan lain sebagainya.

3. Intelligensi. Seorang anak akan memiliki kecerdasan yang diturunkan oleh orang tua kepadanya sekalipun ia diasuh oleh orang lain dalam kehidupannya. J.J Rousseau menyatakan seorang anak yang cerdas dihasilkan dari orang tua yang cerdas. Terdapat literatur substansial yang menghubungkan kognisi dengan ukuran dan struktur otak. Misalnya, korelasi rata-rata antara ukuran otak dan kecerdasan telah dilaporkan menjadi sekitar 0,33 . telah dikemukakan bahwa korelasi tersebut terkait dengan faktor genetik (Stenberg \& Preiss, 2010).

4. Kepribadian. Setiap individu memiliki kepribadian yang unik yang berbeda antara satu dengan yang lainnya. Kepribadian merupakan organisasi dinamis dalam aspek fisiologis, kognitif maupun afektif yang dapat mempengaruhi pola perilaku individu dalam menyesuaikan diri dengan lingkungan sekitarnya. Selain dipengaruhi faktor interaksi dalam lingkungan sekitanya, kepribadian juga dipengaruhi oleh faktor bawaaan atau genetis. Dalam perspektif psikologi perkembangan, kepribadian dalam diri anak, baik normal maupun abnormal, pada dasarnya diturunkan dari orang tua (Amini \& Naimah, 2020). 


\section{Lingkungan dalam Pembentukan Karak- ter}

Lingkungan merupakan segala sesuatu yang mempengaruhi kehidupan individu hingga individu tersebut ikut terlibat dan terpengaruh di dalamnya (Hadi, 2017). Hal tersebut dikarenakan Individu-individu di masyarakat cenderung mengikuti pola kebiasaan yang berada di lingkungannya baik sadar maupun tidak sadar (Daimah \& Niam, 2019). Lingkungan dengan segala stimulus dan materilnya, baik di luar maupun di dalam dari individu, bersifat fisiologis, psikologis, ataupun sosio-kultural dan tradisi (Maragustam, 2010). Dari segi fisiologis, lingkungan dapat berupa segala kondisi dan material jasmani yang terdapat dalam tubuh seperti vitamin, air, gizi, sistem syaraf dan kesehatan jasmani. Dari segi psikologis, lingkungan mencakup seluruh stimulasi yang didapat oleh individu sejak masa konsepsi, kelahiran hingga matinya. Contoh stimulasi tersebut yaitu: perasaan, emosi, sifat-sifat, dan tingkat intelektual. Dari segi sosio-kultural, lingkungan dapat meliputi berbagai interaksi, stimulasi, dan kondisi dalam hubungannya dengan perlakuan atau karya milik orang lain. Contohnya seperti pola kehidupan dalam keluarga, kelompok, masyarakat, pendidikan, dan latihan termasuk bimbingan (Fathurrohman, 2016).

Lingkungan menjadi faktor yang sangat signifikan dalam pembentukan karakter individu di samping hereditas. Bahkan sekelompok orang hanya mempercayai bahwa pembentukan dan perkembangan dalam diri individu hanya dipengaruhi oleh faktor lingkungan. Kelompok tersebut merupakan aliran empirisme. Salah satu tokoh utama aliran ini yaitu John Lock. Dengan teori tabularasanya, John Lock menyatakan bahwa tiap individu yang lahir bagaikan kertas putih. Oleh karenanya, lingkunganlah yang akan membentuk corak tulisan dalam kertas putih tersebut (Daimah \& Niam, 2019). Menurut aliran ini bakat dan pembawaan yang dibawa oleh individu sejak ia lahir dianggap tidak memiliki pengaruh (Fathurrohman, 2016).

Dalam hubungannya dengan pembentukan karakter, pendapat John Lock di atas dapat pula dipahami bahwa karakter tidak lahir begitu saja, terdapat sebuah proses yang harus dilewati oleh setiap individu agar karakter dapat melekat dalam dirinya. Proses tersebut mulai dari individu lahir kemudian tumbuh dan berkembang hingga menjadi dewasa (Prasanti \& Fitriani, 2018). Karakter perlu dibina, dibangun, dan dikembangkan melalui sebuah proses panjang (Anisah, 2011).

Lingkungan berpengaruh besar terhadap perkembangan setiap individu sebagaimana hereditas, termasuk dalam perkembangan karakternya. Lingkungan tempat individu tumbuh dan berkembang terbagi dalam beberapa bagian, yakni lingkungan keluarga, sekolah, dan lingkungan sosial masyarakat.

\section{Lingkungan Keluarga}

Keluarga merupakan lembaga pendidikan utama dan pertama dalam kehidupan seorang anak yang dapat menjadi dasar dalam pembentukan sebuah karakter. Untuk menciptakan karakter yang kuat dalam diri anak maka dalam kehidupan keluarga perlu terciptanya suasana yang harmonis dan dinamis dan hal tersebut dalam tercipta jika terbangun komunikasi yang baik dari dua sisi yakni antara orang tua dan anak (Ayun, 2017). Terdapat beberapa faktor lingkungan yang berpengaruh dalam karakteristik dan kemampuan individu, faktor-faktor tersebut yakni: 
a. Pola asuh orang tua. Pola asuh yang diberikan oleh orang tua pada diri anak menjadi faktor utama dalam membentuk potensi dan karakter seorang anak. Terdapat 4 pola asuh orang tua yang berpengaruh dalam diri anak. (1) Pola asuh otoriter. Ciri orang tua dengan pola asuh otoriter yakni selalu membuat keputusan secara sepihak, anak dituntut untuk selalu tunduk dan patuh serta tidak boleh mengemukakan pendapat/bertanya (Ayun, 2017). Anak yang berada di bawah pola pengasuhan orang tua otoriter akan cenderung menarik diri secara sosial, tidak spontan dan memiliki percaya diri yang kurang (Fathurrohman, 2016). (2) Pola asuh demokratis. Orang tua yang memiliki pola asuh demokratis selalu mendorong anak untuk dapat berbicara hal yang diinginkan dengan tetap memberikan batasan serta pengendalian atas tindakan yang dilakukan oleh anak. Anak dalam pola asuh demokratis cenderung lebih percaya diri, memiliki harga diri yang tinggi dan memiliki perilaku yang terpuji (Jannah, 2012). (3) Pola asuh permisif. Dalam pola asuh permisif orang tua cenderung pasif. Orang tua tidak melibatkan diri dalam kehidupan anak-anak mereka. Orang tua lebih mementingkan kehidupan pribadi dan cenderung membiarkan anak untuk tumbuh besar tanpa kasih sayang dan tanpa pemenuhan kebutuhan fisik yang cukup (Jannah, 2012). (4) Pola pengasuhan pemanja. Dalam pola asuh pemanja orang tua memusatkan segala sesuatunya pada kepentingan diri anak tanpa memberikan pembimbingan yang sesuai dengan kebutuhan perkembangan diri anak. Anakanak yang tumbuh dibawah pola asuh orang tua pemanja akan cenderung bersifat manja atau kurang matang secara sosial, bersifat impulsif, egois, serta kurang percaya diri (cengeng) (Fathurrohman, 2016).

b. Status sosial atau ekonomi orang tua. Faktor ini meliputi kekayaan, kekuasaan, dan prestise. Status sosial ekonomi keluarga meliputi pendidikan, pekerjaan dan penghasilan orang tua, selain itu fasilitas khusus dan keberadaan barang-barang berharga dalam rumah (Pratiwi, Mufliha, \& Adini, 2020). Kehidupan seorang anak dalam masyarakat tidak dipandang sebagai anak yang independen, tetapi dipandang dalam konteks yang utuh dalam keluarga. Oleh karenanya dalam pergaulan sosial, seorang anak akan memperhitungkan norma yang berlaku dalam keluarganya (Fathurrohman, 2016).

c. Urutan kelahiran. Beberapa penelitian menunjukan perbedaan-perbedaan individual yang disebabkan oleh urutan kelahiran. Anak sulung dalam sebuah keluarga biasanya lebih pandai menyesuaikan diri dan pandai mengendalikan diri, dan takut gagal namun cenderung pasif jika dibanding dengan adik-adiknya. Berbeda dengan anak sulung, anak tunggal sering kali dipandang sebagai anak yang egosi, kesepian, dan kurang dapat bersosialisasi jika dibanding dengan anak yang lahir memiliki saudara kandung. Hanya saja tidak cukup bukti yang mendukung asumsi tentang tersebut. Seperti halnya anak sulung, anak tunggal dipandang memiliki posisi yang baik dan menguntungkan dalam keluarga. Adapun anak-anak lain, belum tersedia informasi yang cukup mengenai hal ini. Hanya saja berdasarkan data yang didapat pengalaman mereka biasanya tergantung pada banyaknya kakak atau adik di tengah-tengah kehidupan keluarga. Anak tengah cendeung bersikap 
ekstrovert dan kurang dapat berprestasi jika dibanding anak sulung. Anak yang lahir tanpa menghadapi masalah banyak cenderung lebih optimis, memiliki prestasi akademik yang baik, popular, dan memiliki tingkat percaya diri yang tinggi jika dibanding dengan anak sulung (Pratiwi, Mufliha, \& Adini, 2020).

d. Keluarga broken. Seorang anak dalam kehidupannya tumbuh dan berkembang dalam lingkungan keluarga yang berbeda-beda. Beberapa anak mendapat pengasuhan dan dukungan yang baik dari orang tua, sementara orang tua lainnya mengabaikan dan bersikap kasar pada diri anak. Beberapa anak memiliki keluarga yang orang tuanya bercerai sementara anak lain hidup dalam keluarga yang harmonis, beberapa anak hidup dalam keluarga yang berkecukupan sementara anak lainnya hidup dalam kemiskinan (Pratiwi, Mufliha, \& Adini, 2020). Keluarga merupakan lingkungan pertama dalam kehidupan diri anak. Oleh karenanya, orang tua harus tetap menjaga keutuhan dan keharmonisan dalam keluarga guna memberikan layanan pendidikan dan pengembangan yang baik pada potensi diri anak hingga anak dapat mengembangkan potensi yang dimilikinya dengan baik (Fathurrohman, 2016).

\section{Lingkungan Sosial Masyarakat}

Masyarakat merupakan wadah dan wahana pendidikan yang majemuk dalam kehidupan manusia (Fathurrohman, 2016). Seorang anak dapat tumbuh menjadi pribadi yang berkarakter apabila didukung oleh lingkungan yang berkarakter, sehingga fitrah seorang anak yang dilahirkan dalam keadaan suci dapat berkembang dengan baik dan optomal. Oleh karenanya, untuk mengembangkan calon-calon penerus bangsa yang berkarakter merupakan tanggung jawab semua pihak (Prasanti \& Fitriani, 2018).

\section{Lingkungan Sekolah}

Elizabeth B. Hurlock (Hadi, 2017) memandang sekolah sebagai faktor penentu dalam pengembangan kepribadian seorang anak, baik dalam berpikir maupun dalam berperilaku. Dalam lingkungan sekolah, seorang anak berinteraksi dengan guru- guru dan teman-temannya secara tidak langsung. Anak saling mengamati bahkan meniru kebiasaan yang ada di lingkungan sekolah. Oleh karenanya, orang tua harus selalu siap menjadi self control bagi seorang anak agar anak tetap tumbuh dan berkembang dengan karakter yang baik (Prasanti \& Fitriani, 2018).

\section{Hereditas dan Lingkungan dalam Pem- bentukan Diri Individu}

Hereditas dan lingkungan mempengaruhi kehidupan individu bahkan sejak menjadi embrio sampai menjadi manusia yang utuh. Willian Stern berpendapat bahwa dalam perkembangannya, individu dipengaruhi oleh faktor bawaan (hereditas) dan faktor lingkungan (Daimah \& Niam, 2019). Asumsinya yaitu kemampuan bawaan yang baik yang dimiliki oleh individu tidak akan tercetak menjadi pribadi yang ideal tanpa peran lingkungan di dalamnya. Sebaliknya, lingkungan serta pendidikan yang baik tidak akan menghasilkan individu yang ideal tanpa didukung oleh kemampuan dasar yang baik pula. Dengan demikian, hereditas saja dianggap tidak cukup mampu untuk mengembangkan individu secara potensial dan lingkungan saja tidak memiliki arti apa-apa dalam mengembangkan individu sebagaimana yang diharapkan (Fathurrohman, 2016). 
Pencampuran yang kuat antardua faktor tersebut menyulitkan bagi siapa pun untuk merujuk pada salah satunya dalam menentukan manakah yang lebih dominan dalam pembentukan pribadi manusia. Namun, beberapa keadaan pertumbuhan jasmani dalam diri indvidu dapat merujuk pada faktor hereditas seperti warna kulit, mata, warna rambut, dan sebagainya. Oleh karenanya, faktor hereditas senantiasa mempengaruhi perkembangan jasmani, sedang beberapa bentuk kepribadian dan perilaku sosial dapat merujuk pada faktor lingkungan (Daimah \& Niam, 2019).

Faturrohman (2016) menyatakan terdapat dua faktor yang mempengaruhi tinggi rendahnya perkembangan individu, yakni: (1) faktor internal. Faktor internal merupakan faktor yang terdapat dalam diri individu, meliputi pembawaan dan potensi psikologis tertentu yang ikut serta dalam mengembangkan potensi dirinya; dan (2) faktor eksternal. Faktor eksternal yakni faktor hal-hal yaang berasal dari luar diri individu, seperti lingkungan (pendidikan) serta hasil pengalaman interaksi individu dengan lingkungannya. Apabila kedua faktor tersebut ada dalam diri individu, maka ia akan mudah menerima segala bentuk pendidikan dan mampu mewujudkan tujuan dalam pendidikan sebagaimana yang diharapkan, yakni mampu menjadi individu yang insan kamil yang mampu mengemban dan menjalankan tugasnya sebagai manusia.

\section{SIMPULAN}

Faktor hereditas atau yang lebih dikenal sebagai faktor bawaan merupakan karakteristik bawaan yang diwariskan orang tua ke dalam diri anak sejak masa pembuahan. Faktor lingkungan merupakan segala sesuatu yang berpengaruh dalam kehidupan individu. Dari masa konsepsi hingga masa-masa selanjutnya, perkembangan individu dipengaruhi oleh kualitas makanan yang diperolehnya, temperatur udara di sekitarnya, suasanasuasana di lingkungannya, sikap orang sekitar dan hubungannya dengan orang sekitar, serta suasana pendidikan yang diperolehnya (formal dan informal). Dua faktor ini (hereditas dan lingkungan) mempengaruhi individu dan berinteraksi dengannya sejak pertama menjadi embrio sampai ke akhir hidupnya. Beberapa keadaan pertumbuhan jasmani dalam diri indvidu dapat merujuk pada faktor hereditas seperti warna kulit, mata, warna rambut, dan sebagainya, sedang beberapa bentuk kepribadian dan perilaku sosial dapat merujuk pada faktor lingkungan

\section{UCAPAN TERIMA KASIH}

Penulis mengucapkan terima kasih kepada Dr. Eva Latifah, M.Si., yang telah membimbing penulis menyelesasikan tulisan ini sehingga tulisan ini dapat digunakan menjadi salah satu sumber acuan dalam penelitian yang akan datang. Ucapan terima kasih juga disampaikan kepada dewan redaksi Jurnal Pendidikan Karakter yang mau menerima artikel ini hingga dapat dimuat di terbitan edisi sekarang ini.

\section{DAFTAR PUSTAKA}

Amini, N. \& Naimah. (2020). Faktor hereditas dalam mempengaruhi perkembangan intelligensi anak usia dini. Jurnal Buah Hati, 7(2), 108-124. DOI: https://doi.org/10.46244/buahhati.v 7i2.1162.

Anisah, A.S. (2011). Pola asuh orang tua dan implikasinya terhadap pembentukan karakter anak. Jurnal Pendidikan Universitas Garut, 5(1), 70-84. DOI:http:/dx.doi.org/10.52434/jp.v5i1.4. 
Ayun, Q. (2017). Pola asuh orang tua dan metode pengasuhan dalam membentuk kepribadian anak. Jurnal Inovasi Pendidikan Guru, 5(1), 102-122. DOI: http://dx.doi.org/10.21043/thufula. v5i1.2421.

Daimah \& Niam, Z.W. (2019). Landasan filosofis pembelajaran agama Islam perspektif hereditas, lingkungan, kebebasan manusia dan inayah Tuhan. At-Tarbiyat: Jurnal Pendidikan Islam, 2(2), 158-172. DOI: https://doi.org/10.37758/jat.v2i2.159.

Fathurrohman, M. (2016). Pembawaan, keturunan, dan lingkungan dalam perspektif Islam. Kabilah: Journal of Social Community, 1(2), 379-406. Retrieved from http:// ejournal.kopertais4.or.id/madura/index.php/kabilah/article/view/2868.

Hadi, I. A. (2017). Pentingnya pengenalan tentang perbedaan individu anak dalam efektivitas pendidikan. Inspirasi: Jurnal Kajian dan Penelitian Pendidikan Islam, 1(1), 71-92. Retrieved from https://ejournal.undaris.ac.id/index. php/inspirasi/article/view/5.

Jannah, H. (2012). Bentuk pola asuh orang tua dalam menanamkan perilaku moral pada anak usia di Kecamatan Ampek Angkek. Jurnal Ilmiah Pesona PAUD, 1(1). DOI: https://doi.org/$10.24036 / 1623$.

Maragustam. (2018). Filsafat pendidikan Islam menuju pembentukan karakter. Yogyakarta: Pasca Sarjana Fakultas Ilmu Tarbiyah dan Keguruan (FITK) Universitas Islam Negeri Sunan Kalijaga.

Mirzaqon, A. (2018). Studi kepustakaan mengenai landasan teori dan praktik konseling expressive writing. Jurnal BK UNESA, 8(1), 1-8. Retrieved from https://jurnalmahasiswa.unesa.ac.id /index.php/jurnal-bk-unesa/article/ view/22037.

Prasanti, D., \& Fitriani, D. K. (2018). Pembentukan karakter anak usia dini: keluarga, sekolah, dan komunitas? Jurnal Obsesi: Jurnal Pendidikan Anak Usia Dini, 2(1), 13-19. DOI: https://doi.org/10.31004/obsesi.v2i1.2.

Pratiwi, A.R., Mufliha, D., \& Adini, P. (2020). Sumber perbedaan individu pada siswa sekolah dasar. Jurnal Pendidikan dan Dakwah, 2(1), 134-148. DOI: https:// doi.org/10.36088/pandawa. v2i1.629.

Sarwono, J. (2006). Metode penelitian kuantitatif dan kualitatif. Yogyakarta: Graha Ilmu.

Sholihah, D. \& Niam, Z.W. (2019). Landasan filosofis pembelajaran agama Islam perspektif hereditas, lingkungan, kebebasan manusia dan inayah Tuhan. At-Tarbiyat: Jurnal Pendidikan Islam, 2(2), 158-172. DOI: https://doi.org/10.37758/jat.v2i2.159.

Stenberg, R.J., \& Preiss, D.D. (2010). Innovations in educational psychologi: perspektives on learning, teaching, and human development. New York: Springer Publishing Company.

Tibahary, A.R., \& Muliana, M. (2018). Model-model pembelajaran inovatif. Scolae: Journal of Pedagogy, 1(1), 54-64. Retrieved from http://ejurnal.stkipdamsel.ac.id/index.php/scl/article/ view/12. 